DOI: https://doi.org/10.11144/Javeriana.upsy17-3.eicb

\title{
Evaluation of the Impact of a Cognitive- Behavioral Intervention for Women in Domestic Violence Situations in Brazil ${ }^{*}$
}

\section{Evaluación del impacto de una intervención cognitivo-conductual para mujeres en situación de violencia doméstica en Brasil}

Received: 07 January 2016 | Accepted: 24 July 2017

\author{
Luisa Fernanda Habigzanga \\ Pontifical Catholic University of Rio Grande do Sul, \\ Brazil \\ ORCID: http://orcid.org/0000-0002-0262-0356 \\ Jaluza Aimèe Schneider \\ Pontifical Catholic University of Rio Grande do Sul, \\ Brazil \\ Rafaela Petroli Frizzo \\ Vale do Rio dos Sinos University, Brazil \\ Clarissa Pinto Pizarro de Freitas \\ Salgado de Oliveira University, Brazil
}

\begin{tabular}{l}
\hline a Correspondence author. Email : \\
habigzang.luisa@gmail.com
\end{tabular}

How to cite: Habigzang, L. F., Aimèe Schneider, J., Petroli Frizzo, R., \& Freitas, C. P. (2018). Evaluation of the Impact of Cognitive-Behavioral Intervention for Women in Domestic Violence Situations in Brazil. Universitas Psychologica, 17(3), 1-11. doi: https://doi. org/10.11144/Javeriana.upsy17-3.eicb

\begin{abstract}
Domestic violence against women constitutes a serious public health problem, which requires effective interventions for its prevention and treatment. This study aimed to develop and evaluate an intervention protocol, based on cognitive-behavioral therapy, for women in situations of domestic violence. The sample was composed of 11 women that were victims of psychological, physical, and/or sexual violence perpetrated by their partners. Symptoms of anxiety, depression, stress and posttraumatic stress disorder (PTSD) and life satisfactions levels were evaluated before and after the 13 individual psychotherapy sessions. The intervention protocol consisted of psychoeducation techniques, cognitive restructuring, gradual exposure to traumatic memories, problem resolution and recurrence prevention. Results showed a significant reduction in depression, anxiety and stress symptoms. The life satisfaction levels also increased significantly after the intervention, however, PTSD symptoms remained stable. These results constitute initial evidence for the effectiveness of the intervention. In Brazil, there is a lack of evidencebased interventions for the treatment of this population, thus, this study contributes by presenting an evidence-based intervention that may be used to qualify the actions of the public mental health services.
\end{abstract}

Keywords

domestic violence; effectiveness; psychotherapy; cognitive behavioral therapy.

\section{RESUMEN}

La violencia contra la mujer en el contexto conyugal es un grave problema de salud pública, lo que hace necesarias intervenciones efectivas para la prevención y el tratamiento. El presente estudio tuvo como objetivo desarrollar y evaluar la efectividad de un protocolo de intervención 
basado en la terapia cognitivo-conductual para mujeres en situación de violencia conyugal. La muestra estuvo compuesta por 11 mujeres que experimentaron situaciones de violencia psicológica, física y/o sexual perpetradas por sus parejas. Se evaluaron síntomas de ansiedad, depresión, estrés y trastorno de estrés postraumático (TEPT) antes y después de 13 sesiones de psicoterapia individual. Además, se evaluaron niveles de satisfacción con la vida. El protocolo de intervención estuvo compuesto por técnicas de psicoeducación, reestructuración cognitiva, exposición gradual a recuerdos traumáticos, resolución de problemas y prevención de recaídas. Los resultados indicaron reducción significativa de síntomas de depresión, ansiedad y estrés. Los niveles de satisfacción con la vida aumentaron significativamente después de la intervención. Sin embargo, los síntomas de TEPT se mantuvieron estables. Estos resultados constituyen evidencias iniciales de la efectividad de la intervención. Se identifica la carencia de protocolos con evidencias de efectividad para el tratamiento de esa población en Brasil. Estudios como este pueden contribuir a mejorar las acciones de los servicios de salud mental.

Palabras clave

violencia doméstica; efectividad; psicoterapia; terapia cognitivoconductual.

Violence against women is considered a global health problem (World Health Organization [WHO], 2013). In Brazil, the national policy to combat violence against women characterizes this phenomenon as a violation of human rights, which occurs in different cultures, regardless of the social, economic, ethnic or age context (Secretaria de Políticas para as Mulheres, 2011). Other terms to define the phenomenon are gender-based violence, domestic violence and intimate partner violence. Due to the consequences of domestic violence for the victims and their family members, as well as the high levels of prevalence, this form of violence constitutes a complex problem and requires public policies for its prevention and psychosocial treatment (Jonas et al., 2014; Secretária de Transparência, 2013; WHO, 2013).

The first report from a global systematic study on violence against women reveals that approximately $30 \%$ of women worldwide are victims of aggression perpetrated by their partners (WHO, 2013). In the Brazilian context, the Map of Violence, published in 2012 by the Ministry of Health, found that in $42.5 \%$ of the cases these acts of aggression were committed by the partner or former partner of the victim, which constitutes domestic violence. The same study also found that in $68.8 \%$ of the cases cases it was identified that the victim's residence was the site of the occurrence of the aggression (Centro Brasileiro de Estudos LatinoAmericanos [Cebela] \& Faculdade LatinoAmericana de Ciências Sociais [FLACSO], 2012).

In 2006, Brazil Law No. 11.340 was enacted, called the Maria da Penha Law, aiming to provide formal strategies to protect women who suffer domestic violence. This law constitutes one of the principal global legal processes that aims to combat violence against women (Secretaria de Políticas para as Mulheres, 2011). Situations involving physical, property, sexual, moral and psychological violence are characterized as crimes and must be monitored by the Protection Network.

Individual and cultural factors act in the commission and maintenance of the cycle of violence against women in conjugal relationships. Financial and emotional dependency, fear, guilt, skepticism regarding the implementation of effective protection measures, gender differences and inequality are some of these factors (Soares, Silva, Medeiros, Dias, \& Moura, 2013).

Living in a situation of violence in the domestic context constitute a major stressor. Ill-treatment suffered by women generates significant negative consequences for their physical and mental health, as well as their social relationships (Fonseca, Ribeiro, \& Leal, 2012; Gomes et al., 2012). The literature indicates that women in situations of domestic violence have a greater probability of developing psychiatric disorders. The main ones are mood disorders, anxiety disorders, post-traumatic stress disorder (PTSD), substances use disorders and obsessive-compulsive disorder (Adeodato, Carvalho, Siqueira, \& Souza, 2005; Devries et al., 2011; Dillon, Hussain, Loxton, \& Rohman, 2013; Jonas et al., 2014). For this reason, a high use of psychiatric drugs and suicide risk can be verified in this population (Adeodato et al., 2005; 
Dillon et al., 2013; Hatzenberger, Lima, Lobo, Leite, \& Kristensen, 2010; Souza et al., 2013).

The consequences described require interventions aimed at minimizing the impact of the violence. Thus, psychotherapeutic monitoring, which includes effective and evidence-based techniques, is essential for the improvement of the quality of life of women in situations of domestic violence (Courtois \& Ford, 2009). From this perspective, some recent studies have aimed to develop and evaluate the results of psychotherapeutic interventions for these women (Crespo \& Arinero, 2010; Dutton, Bermudez, Matas, Majid, \& Myers, 2013; Echeburúa, Sarasua, \& Zubizarreta, 2013; Hansen, Eriksen, \& Elklit, 2014; Iverson, Shenk, \& Fruzzetti, 2009).

A Danish study aimed to determine the effects of a semi-structured multidisciplinary intervention developed for female victims of traumatic events linked to domestic violence (Hansen et al., 2014). The intervention consisted of three phases with the respective goals: 1) stabilization of their physical and social safety, as well as legal assistance; 2) psychotherapeutic treatment, with semistructured sessions, directed toward the exposure of the traumatic experiences and the reduction of the psychological symptoms; and 3) monitoring after the treatment for six months. The results of the intervention showed a significant reduction in symptoms of PTSD, anxiety and depression, and increased the perception of social support in the 70 women who completed the three steps (Hansen et al., 2014).

Dutton et al. (2013) evaluated the results of an intervention based on the practice of Mindfulness Based Stress Reduction (MBSR) with women in situations of domestic violence. The authors conducted MBSR sessions with 53 American low-income women, who had been victims of violence and who presented PTSD symptoms. These women reported greater confidence and self-efficacy, greater anger control and mainly perceived greater focus on the present, reducing the re-experiencing symptoms associated with PTSD. Despite the positive selfreports of the women, an important limitation of this study was the absence of psychological instruments for the evaluation of the results of the intervention (Dutton et al., 2013).

Another approach evaluated for the treatment of women victims of violence is dialectical behavioral therapy (DBT - Iverson et al., 2009). Dialectical behavioral therapy was developed to treat severe cases characterized by emotional dysregulation, for example, subjects exposed to repeated violent events. Using this approach, in the study by Iverson et al. (2009), 31 women victims of violence participated in 12 group DBT sessions adapted for this population. The study results were positive, including significant improvements in relation to depressive symptoms, hopelessness, psychological distress and social adjustment.

Cognitive-behavioral therapy (CBT) was also effective, through an intervention with 17 semistructured sessions, for 116 women abused by former partners that sought help in a specialized mental health service in Spain (Echeburúa et al., 2013). The CBT model resulted in a significant reduction of PTSD symptoms and positive changes in relation to emotional distress and impaired functionality. These results were identified immediately after the intervention and maintained after 12 months. The intervention was tested in two ways: individual and combined (individual and group). Positive results were found in both cases (Echeburúa et al., 2013). Finally, Crespo, and Arinero (2010) found satisfactory results in the application of a group CBT program. The study was conducted with 53 women with histories of domestic violence and PTSD diagnoses. The participants of the group presented significant reductions in the symptoms of PTSD, depression and anxiety. The results were maintained over the 12 months of evaluation (Crespo \& Arinero, 2010).

In Brazil, few studies have been performed that address the development and evaluation of psychological interventions for female victims of domestic violence. Such research is fundamental to improve the care provided by the agencies that make up the public health and social services network. Therefore, this study aimed to develop and evaluate the results of a psychotherapeutic 
intervention based on CBT for women in domestic violence situations.

\section{Method}

\section{Design}

This was a quasi-experimental study, including a pre-test evaluation, followed by the intervention and a post-test evaluation, with a single group (Sampieri, Collado, \& Lucio, 2013). The evaluation of the effectiveness of the intervention was performed by comparing depression, anxiety, PTSD and stress symptoms, and the perception of life satisfaction in the pretest (T1 before the intervention) and post-test (T2 after the intervention).

\section{Participants}

The study was conducted in partnership with a Reference Center for women in the metropolitan region of Porto Alegre, Rio Grande do Sul state. The institution referred 120 cases of women in situations of violence for evaluation and psychological intervention. Among the referred cases, 11 women completed the intervention (see Figure 1). Inclusion criteria were: to present a history of domestic violence; to be aged 18 years or over; and to complete the intervention protocol. Exclusion criteria were: the use of psychotropic drugs; to present severe cognitive impairment; or to present severe psychotic symptoms.

\section{Figure 1}

Flowchart of referral of the participants

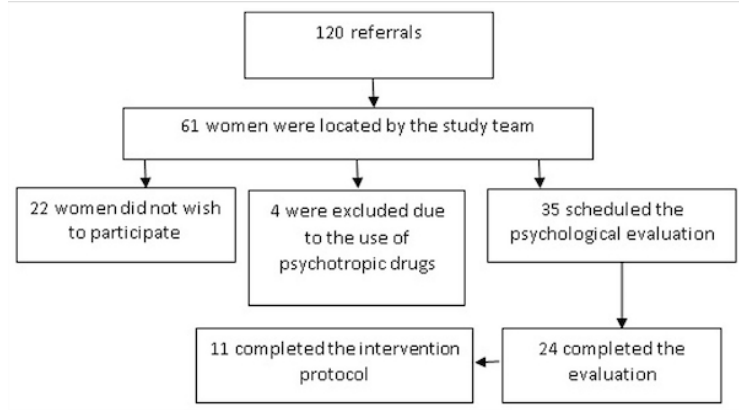

The study sample consisted of 11 women in domestic violence situations, with mean age 42.73 years $(\mathrm{SD}=9.5)$. The marital status of the participants was $9 \%$ single $(n=1), 18 \%$ married $(n=2), 64 \%$ separated $(n=7)$ and $9 \%$ widowed $(n=1)$. The level of education was: $9 \%$ with no education $(n=1), 9 \%$ incomplete elementary education $(n=1), 27 \%$ complete elementary education $(n=3), 9 \%$ incomplete high school education $(n=1), 27 \%$ complete high school education $(n=3)$ and $18 \%$ incomplete higher education $(n=2)$. The types of violence reported by the women at the time of psychological evaluation were $27 \%$ psychological $(n=3), 45 \%$ physical $(n=5)$ and psychological and physical $27 \% \ldots ”(n=3)$, psychological and sexual $(n=3)$.

\section{Instruments}

(1) Semi-structured initial interview: - used in order to evaluate the general aspects of the participant's life, collect sociodemographic data, and comprehend the history of violence (frequency, length of exposure, type of violence, protective measures adopted, and protection network of the victim).

(2) Beck Anxiety Inventory (BAI - Beck, Epstein, Brown, \& Sterr, 1988 adapted by Cunha, 2001): A 21 items scale that investigates anxiety levels. The original scale has a unifactorial structure with satisfactory Cronbach's alpha coefficient $(\alpha=0.92)$.

(3) Beck Depression Inventory (BDI - Beck, Ward, Mendelson, Mock, \& Erbauch, 1961, adapted by Gorenstein \& Andrade, 1996): This scale evaluates depression levels through 21 questions and has a unifactorial structure. The original version of the scale presented a satisfactory Cronbach's alpha coefficient $(\alpha=$ $0.86)$.

(4) Satisfaction with Life Scale (SWLS - Diener, Emmons, Larsen, \& Griffin, 1985, adapted by Gouveia, Milfont, da Fonseca, \& Coelho, 2009): This scale consists of five statements that evaluate subjective well-being and life satisfaction using a Likert scale of seven points (Diener et al., 1985). 
(5) Structured interview based on DSM IV/ SCID used to assess PTSD (Del Ben et al., 2001): The diagnostic criteria of the DSM-IV, current during the collection period, were used to identify the symptoms of re-experiencing, avoidance and hyperarousal, characteristic of PTSD.

(6) Lipp Inventory of Stress Symptoms for Adults (LISS - Lipp, 2000): Aims to evaluate stress levels through a general score. The inventory consists of 53 items, divided into three sections referring to the phases of stress experienced in the previous 24 hours, previous week and previous month. The stress subscales presented adequate internal consistency (daily stress, $\alpha=0.50$, weekly stress, $\alpha=0.75$, monthly stress, $\alpha=0.77$ ). The stress level evaluation is provided by the sum of the symptoms of each subscale. Based on the scores of the three subscales, five stress levels can be categorized: not stressed; alert; resistance; near-exhaustion; and exhaustion.

\section{Procedures}

The project was submitted to and approved by the Research Ethics Committee of Federal University of Rio Grande do Sul (Authorization No. 20317). After approval by the Ethics Committee, the research team received 16 hours training that aimed to train them in the psychological evaluation procedures and the application of the cognitive-behavioral intervention protocol. The next step was the establishment of the partnership with the women protection agencies for the referral of the participants.

The participants referred were evaluated in three individual interviews of one hour duration and weekly frequency, in which the psychological evaluation instruments were applied. The order of application of the instrument was changed at random to prevent an order effect on the results. After the individual psychological evaluation, the participants were referred for the individual cognitive-behavioral intervention. The description of the intervention is presented in Table 1.
Table 1

Description of the intervention sessions

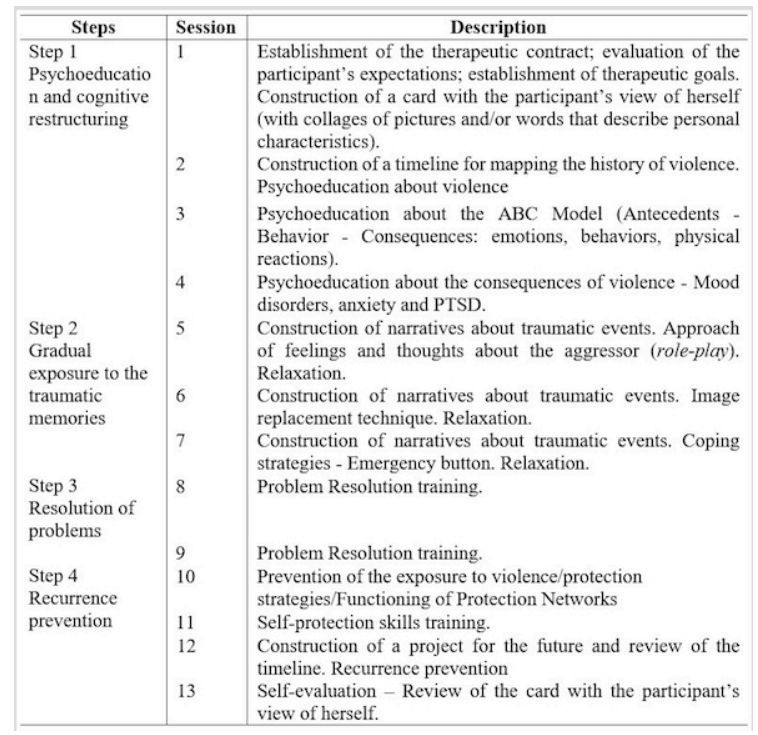

The cognitive-behavioral intervention consisted of 13 sessions with a weekly frequency. The sessions included structured activities of one hour duration. The intervention process was divided into four steps according to the techniques employed: Step 1 - Psychoeducation and cognitive restructuring (four sessions); Step 2 - gradual exposure to the traumatic memories and relaxation (three sessions); Step 3 - Problem resolution (two sessions) and Step 4 - Recurrence prevention (four sessions). At the end of the psychotherapeutic process, the participants answered the psychological evaluation instruments individually. The initial and final evaluations were carried out by researchers who had not taken part in the therapeutic process.

\section{Data analysis}

The indices of anxiety, depression and life satisfaction of the participants were initially investigated, using descriptive statistics. The presence of PTSD diagnosis and the stress levels were evaluated through the frequency distribution. The correlations between anxiety, depression, life satisfaction and stress were investigated through Spearman's Rho. Point- 
biserial correlations were developed in order to investigate the associations of PTSD diagnosis, categorical variable, with the other variables investigated in the study.

The analyses performed to assess the impact of the intervention were developed through nonparametric tests, as the evaluation of distribution normality, verified through the KolmogorovSmirnov and Shapiro-Wilk tests, indicated the non-normality of the data $(\mathrm{p}<0.05)$. Due to the sample size, the exact probability test (Monte Carlo) was used, since the use of this method combined with the non-parametric tests presents greater accuracy (Field, 2005). The Wilcoxon signed-rank test and exact probability tests were used to investigate the impact of the psychotherapeutic intervention on anxiety levels, depression, life satisfaction, and stress, with scores of the participants before and after the intervention.

The impact of the intervention on PTSD was evaluated through the differences in the presence of the diagnosis of the disorder before and after the intervention. The McNemar test was used, as this variable was dichotomous (1presence; 2-absence). In addition, the Wilcoxon signed-rank test and exact test probability tests were performed to investigate whether the symptoms in the PTSD dimensions (reexperiencing, avoidance and hyperarousal) presented a significant decrease between the beginning and end of the intervention.

\section{Results}

The descriptive results of the study, being the means, standard deviations, frequencies, the internal consistency of the instruments $(\alpha)$ and the Spearman's Rho and Point-biserial correlations are presented in Table 2 . The internal consistency values in all the scales were adequate, i.e., above 0.60 , which is a value considered satisfactory (Nunnally \& Bernstein, 1994).

\section{Table 2}

Means, Standard Deviation, Frequency, Internal Consistency and Spearman's (a) and Point-biserial Correlations (b) of the Sample $(N=11)$

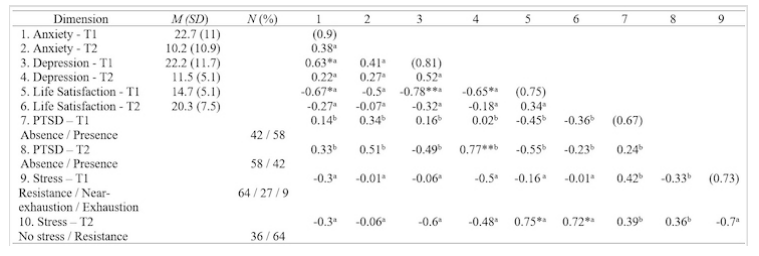

$$
\begin{aligned}
& \text { Note: * }-p \leq .05 ; *-p \leq .001 ; M-\text { Medium; } \\
& \text { SD - Standard Deviation; } N=\text { Frequency; a } \\
& \text { - Spearman's Correlations; } b \text { - Point-biserial } \\
& \text { Correlations; Internal consistency (Cronbach's } \\
& \alpha \text { ), in parentheses, presented diagonally }
\end{aligned}
$$

It was observed that the depression indices at the start of the intervention were positively related to the anxiety levels $(r=0.63, p \leq$ 0.05 , medium effect size, $r^{2}=0.40$ ) and not associated with the other variables evaluated. The life satisfaction indices of the participants negatively correlated with the indices of anxiety $\left(r=-0.67, p \leq 0.05\right.$, medium effect size, $r^{2}=$ $0.45)$ and depression at the start and end of intervention (respectively, $r=-0.78, p \leq 0.001$, large effect size, $r^{2}=0.61$, and $r=-0.65, p$ $\leq 0.05$, medium effect size, $r^{2}=.42$ ). After the participants completed the intervention, it was also found that the presence of PTSD diagnosis was positively associated with the levels of depression $(r=0.77, p \leq 0.001$, large effect size, $\left.r^{2}=0.59\right)$. The stress levels at the beginning of the intervention were not associated with the other variables investigated. The stress levels at the end of the intervention were only negatively associated with life satisfaction indices at the beginning and end of the intervention (respectively, $r=-0.75, p \leq 0.05$, large effect size, $r^{2}=0.56$, and $r=-0.72, p \leq 0.05$, medium effect size, $r^{2}=0.52$ ).

The results showed a significant reduction in the indices of anxiety, depression and a significant increase in life satisfaction levels. Regarding the stress categories, the data suggest a significant reduction in stress phases in the comparison between the start and end of the intervention. The differences in the diagnosis of PTSD before and after the intervention were 
not significant, with no significant differences in the symptoms of re-experiencing, avoidance and hyperarousal (Table 3). The effect size of the differences between the levels of anxiety (large effect size, $r=0.55$ ), depression (large effect size, $r=0.60$ ), life satisfaction (large effect size, $r=0.49$ ) and stress (large effect size, $r=0.51)$ ranged from medium to large, showing the effectiveness of the intervention to reduce anxiety, depression, stress and increase life satisfaction.

\section{Table 3}

Longitudinal Analysis of the Dimensions of Anxiety (BAI), Depression (BDI), Life Satisfaction

(SWLS), Stress (LISS), Diagnosis of PTSD and of the Re-experiencing, Avoidance, and Hyperarousal Dimensions of PTSD at T1 and T2

\begin{tabular}{|c|c|c|c|c|c|c|}
\hline & \multicolumn{2}{|c|}{ Pre-test } & \multicolumn{2}{|c|}{ Post-test } & \multirow{2}{*}{$\begin{array}{c}\text { Wilcoxon } \\
\text { Signed-Rank } \\
\text { (T1 } x \text { T2) }\end{array}$} & \multirow{2}{*}{$\begin{array}{c}\text { McNemar } \chi^{2} \\
(\mathrm{~T} 1 \times \mathrm{T} 2)\end{array}$} \\
\hline & $M(S D)$ & $\%$ & $M(S D)$ & $\%$ & & \\
\hline Anxiety & $22.7(11)$ & & $10.2(10.9)$ & & $-2.6^{* *}$ & \\
\hline Depression & $21.3(11.7)$ & & $11.5(5.1)$ & & $-2.84 * *$ & \\
\hline Life Satisfaction & $14.7(5.1)$ & & $20.3(7.5)$ & & $-2.29^{*}$ & \\
\hline Stress & $2.38(0.9)$ & & $1.27(1)$ & & $-2.4^{* * *}$ & \\
\hline PTSD & & & & & & 0.45 \\
\hline Presence & & 73 & & 18 & & \\
\hline Absence & & 27 & & 82 & & \\
\hline Re-experiencing & $3.3(1.8)$ & & $2(1.3)$ & & -1.6 & \\
\hline Avoidance & $3.2(1.9)$ & & $2.4(1.9)$ & & -1 & \\
\hline Hyperarousal & $2.9(2)$ & & $1.4(1.9)$ & & -1.4 & \\
\hline
\end{tabular}

\section{Discussion}

Initially, it should be noted that the inclusion in the protection network enabled the research team to experience the difficulties in performing work with women in situations of violence, especially domestic violence. Despite a significant number of referrals, many women were not located. According to the professionals working in the institution where the data were collected, the women change the address and telephone contact with relative frequency as a protection strategy. Thus, the team had difficulties in contacting a significant number of cases referred for study participation. Among the women that expressed interest in participating in the study, only 11 completed all the steps (evaluation, intervention and reevaluation). The others had trouble reconciling working hours and care of children or moved from the city during the study.
The psychological evaluation proved to be an important step in the completion of the intervention, providing knowledge about the extent of the consequences caused by the violence (Hatzenberger et al., 2010; Ribeiro, Andreoli, Ferri, Prince, \& Mari, 2009). Furthermore, the instruments used for the evaluation were useful for identifying symptoms of anxiety, depression, PTSD and stress. The aim of the intervention was to provide an evidence-based treatment for women that were victims of some kind of domestic violence or abuse. Based on that, it is observed that the psychodiagnostic evaluation of each case was fundamental for the intervention to attend the specific psychological demands of the participants. Future investigations should evaluate symptoms of complex trauma and posttraumatic cognitions.

The results indicated that the psychological intervention significantly reduced the symptoms of anxiety, depression and stress. Similar findings were encountered in the studies reviewed (Crespo \& Arinero, 2010; Dutton et al., 2013; Echeburúa et al., 2013; Hansen et al., 2014; Iverson et al., 2009). The cognitive and behavioral techniques used in the intervention were effective to reduce the symptoms of depression, anxiety and stress. Psychoeducation allowed the participants to understand the intergenerational cycle of domestic violence, as well as its different forms ofexpression. Understanding the cycle of domestic violence contributed to women victims resignify their experiences, minimize their feelings of guilt and shame, as well as perceptions that they were responsible for their victimization. Feelings of guilt and shame are associated with symptoms of depression and anxiety. Another component of the intervention that may be associated with the reduction of such symptoms was the promotion of the development of strategies of self-protection. These strategies have allowed women to perceive themselves with control over their current life situation, knowing their existing rights and services that can aid in their protection.

An increase in the life satisfaction levels was also "... verified, although PTSD symptoms, 
however remained stable in the participants. These findings were also observed in other studies in which the participants retained a diagnosis of PTSD, even after participating in/ completing the interventions (Cloitre, Koenen, Cohen, \& Han, 2002; Foa et al., 1999; Vickerman \& Margolin, 2009). A possible explanation for this result was the low number of sessions for the exposure and restructuring of the traumatic memories. The participants presented reports of a significant number of traumatic events throughout life, including situations of physical, psychological and sexual violence in childhood. Therefore, increasing the number of sessions in step 2, with the inclusion of techniques to improve emotional regulation, appears necessary for the possible reduction of PTSD symptoms. Exposure to childhood violence and revictimizations during adulthood can generate symptoms of complex trauma that are intense and persistent (Van der Kolk, Roth, Pelcovitz, Sunday, \& Spinazzola, 2005). In these cases, applying techniques to improve emotional regulation are fundamental to reduce the symptoms of complex trauma disorder. The improvement of emotional regulation is extremely important for victims of domestic violence and child abuse, because this may contribute to lessen their feelings of helplessness and abandonment. Another aspect that may be associated with the maintenance of PTSD symptoms is that some participants still perceived themselves at risk of revictimization. For example, some of the patients were still threatened by their ex-spouses. In addition, they did not feel sufficiently supported by the protective bodies. Furthermore, in Brazil, some of the criminal proceedings are long and women need to go to hearings that expose them to situations of revictimization, because are not conducted in a protective manner. Eventually, they may be blamed for the violence, due to the sexist and misogyny culture in the Brazilian Justice System. In addition, they need to report the events that have occurred several times to professionals who do not always have adequate training for the hearing. Because some professionals may poorly conduct the hearings, the revival of the trauma in each hearing may potentiate symptoms of PTSD of the victims (Meneghel et al., 2011).

The study presented two limitations. The first limitation was the low number of participants, which makes it impossible to generalize the results. The second limitation was the lack of a control group, as it cannot be determined whether the passage of time alone would have reduced these symptoms. However, studies with victims of violence indicate that the consequences of this experience tend to worsen over the long term, demonstrating the chronicity of depression and anxiety symptoms (Sant'Anna \& Baima, 2008; Steel, Sanna, Hammond, Whipple, \& Cross, 2003; Ullman \& Filipas, 2005). The small size of the sample was due to difficulties to access women victims of domestic violence. In addition, some patients showed difficulties to attend to the treatment due the unviabilityof their agenda, because they had to work at the time of the session or take care of their children. Future interventions should take this in account, providing sessions in flexible hours for the participation of women who need to reconcile work and childcare activities.

The results of this study can be considered as early evidence for the effectiveness of the cognitive-behavioral intervention model for women in situations of violence. Future studies, with larger samples, may add new evidence and constitute the basis for the intervention to be applied in public services attending this population in Brazil. Future studies should investigate the effectiveness of the intervention with the extension of the second stage of the intervention in number of sessions and the inclusion of techniques to improve emotional regulation. It is also important to consider symptoms of complex trauma when the participants have a history of childhood maltreatment. Finally, a study focusing on the therapeutic process, with an in-depth analysis of aspects such as therapeutic alliance and specific effects of each intervention element, may qualify the protocol. 


\section{References}

Adeodato, V., Carvalho, R., Siqueira, V., \& Souza, F. (2005). Qualidade de vida e depressão em mulheres vítimas de seus parceiros. Revista de Saúde Pública, 39(1), 108-113. http://doi.org/10.1590/S0034-891 02005000100014

Beck, A. T., Epstein, N., Brown, G., \& Steer, R. A. (1988). An inventory for measuring clinical anxiety: Psychometric properties. Journal of Consulting and Clinical Psychology, 56, 893-897. http://doi.org/10.1037/0022-0 06X.56.6.893

Beck, A. T., Ward, C. H., Mendelson, M., Mock, J., \& Erbauch, G. (1961). An inventory for measuring depression. Archives of General Psychiatry, 4, 53-63. http://doi.org/10.1001/ archpsyc.1961.01710120031004

Brazil, Lei 11.340 de 2006. Cria mecanismos para coibir a violência doméstica e familiar contra a mulher. Agosto 7 de 2006. DOU del 8 de agosto de 2006. Retrieved from http://www.planalto.gov.br/ccivil_03/ ato2004-2006/2006/lei/111340.htm

Brazil, Secretaria de Políticas para as Mulheres. (2011). Política nacional de enfrentamento à violência contra as mulheres. Brasília: Presidência da República. Retrieved from http://www.spm.gov.br/sobre/publicac oes/publicacoes/2011/politica-nacional

Brazil, Secretária de Transparência. (2013). Violência doméstica e familiar contra a mulher. Brasília: DataSenado. Retrieved from https://www.senado.gov.br/senado/da tasenado/pdf/datasenado/DataSenado-Pes quisa-Violencia_Domestica_contra_a_Mu lher_2013.pdf

Centro Brasileiro de Estudos Latino-Americanos \& Faculdade Latino-Americana de Ciências Sociais. (2012). Mapa da violência 2012. In J. J. Waiselfisz (Coord.), Atualização: Homicídio de mulheres no Brasil (pp. 1-26). Retrieved from http://mapadaviolencia.org.br/pdf201 2/MapaViolencia2012_atual_mulheres.pdf

Cloitre, M., Koenen, K. C., Cohen, L. R., \& Han, H. (2002). Skills training in affective and interpersonal regulation followed by exposure: A phase-based treatment for PTSD related to childhood abuse. Journal of Consulting and Clinical Psychology, 70(5), 1067-1074. http://doi.org/10.1037/0022-00 6X.70.5.1067

Courtois, C. A., \& Ford, J. D. (2009). Treating complex traumatic stress disorders: An evidence-based guide. New York: The Guilford Press.

Crespo, M., \& Arinero, M. (2010). Assessment of the efficacy of psychological treatment for women victims of violence by their intimate male partner. The Spanish Journal of Psychology, 13(2), 849-863. https://doi.or $\mathrm{g} / 10.1017 / \mathrm{S} 113874160000250 \mathrm{X}$

Cunha, J. A. (2001). Manual da versão em português das Escalas Beck. São Paulo: Casa do Psicólogo.

Del Ben, C. M., Vilela, J. A., Crippa, J. A., Hallak, J. E., Labate, C. M., \& Zuardi, A. W. (2001). Confiabilidade da entrevista estruturada para o DSM-IV--Versão clínica traduzida para o português. Revista Brasileira de Psiquiatria, 23(3), 156-159. http://doi.org/1 0.1590/S1516-44462001000300008

Devries, K., Watts, C., Yoshihama, M., Kiss, L., Schraiber, L. B., Deyessa, N., ... \& Berhane, Y. (2011). Violence against women is strongly associated with suicide attempts: evidence from the WHO multi-country study on women's health and domestic violence against women. Social science $\mathcal{E}$ medicine, 73(1), 79-86. https://doi.org/10.1 016/j.socscimed.2011.05.006

Diener, E., Emmons, R. A., Larsen, R. J., \& Griffin, S. (1985). The Satisfaction with Life Scale. Journal of Personality Assessment, 49, 71-75. Retrieved from https://internal.psychology.illinois.ed $\mathrm{u} / \sim$ ediener/Documents/Diener-EmmonsLarsen-Griffin_1985.pdf

Dillon, G., Hussain, R., Loxton, D., \& Rohman, S. (2013). Mental and physical health and intimate partner violence against women: A review of the literature. International Journal of Family Medicine, 1-15. http://doi. org/10.1155/2013/313909 
Dutton, M. A., Bermudez, D., Matas, A., Majid, H., \& Myers, N. (2013). Mindfulness based stress reduction for low-income, predominantly African American women with PTSD and a history of intimate partner violence. Cognitive and Behavioral Practice, 20, 23-32. http://doi.org/10.1016/j.cbpra.20 11.08 .003

Echeburúa, E., Sarasua, B., \& Zubizarreta, I. (2013). Individual versus individual and group therapy regarding a cognitivebehavioral treatment for battered women in a community setting. Journal of Interpersonal Violence, 29(10), 1783-1801. http://doi.org/ 0886260513511703

Field, A. (2005). Discovering Statistics Using SPSS (2nd. ed.). London: Sage.

Foa, E. B., Dancu, C. V., Hembree, E. A., Jaycox, L. H., Meadows, E. A., \& Street, G. P. (1999). A comparison of exposure therapy, stress inoculation training, and their combination for reducing posttraumatic stress disorder in female assault victims. Journal of Consulting and Clinical Psychology, 67(2), 194-200. http://doi.org/10.1037/002 2-006X.67.2.194

Fonseca, D. H., Ribeiro, C. G., \& Leal, N. S. B. (2012). Violência doméstica contra a mulher: Realidades e representações sociais. Psicologia $\mathfrak{E}$ Sociedade, 24(2), 307-314. Retrieved from http://www.ufrgs.br/seerpsicsoc/ojs/vi ewarticle.php?id $=1069$

Gomes, N. P., Garcia, T. C. S., Conceição, C. R., Sampaio, P. O., Almeida, V. C., \& Paixão, G. P. N. (2012). Violência conjugal: Elementos que favorecem $\mathrm{O}$ reconhecimento do agravo. Saúde em Debate, 36(95), 514-522. http://doi.org/10. 1590/S0103-65642014000100007

Gorenstein, C., \& Andrade, L. (1996). Validation of a Portuguese version of the Beck Depression Inventory and the State-Trait Anxiety Inventory in brasilein subjects. Brazilian Journal of Medical and Biological Research, 29(4), 453-457. Retrieved from http://europepmc.org/abstr act/MED/8736107
Gouveia, V. V., Milfont, T. L., da Fonseca, P. N., \& Coelho, J. A. P. de M. (2009). Life satisfaction in Brazil: Testing the psychometric properties of the satisfaction with Life Scale (SWLS) in five Brazilian samples. Social Indicators Research, 90(2), 267-277. http://doi.org/10.1007/s11205-00 8-9257-0

Hansen, N. B., Eriksen, S. B., \& Elklit, A. (2014). Effects of an intervention program for female victims of intimate partner violence on psychological symptoms and perceived social support. European Journal of Psychotraumatology, 5(1), 1-10. http://doi .org/10.3402/ejpt.v5.24797

Hatzenberger, R., Lima, A. V. R., Lobo, B., Leite, L., \& Kristensen, C. H. (2010). Transtorno de estresse pós-traumático e prejuízos cognitivos em mulheres vítimas de violência pelo parceiro íntimo. Ciências Eु Cognição, 15(2), 94-110. Retrieved from http://www.cienciasecognicao.org/rev ista/index.php/cec/article/view/277

Iverson, K. M., Shenk, C., \& Fruzzetti, A. E. (2009). Dialectical behavior therapy for women victims of domestic abuse: A pilot study. Professional Psychology: Research and Practice, 40(3), 242-248. http://doi.org/10.1 $037 / \mathrm{a} 0013476$

Jonas, S., Khalifeh, H., Bebbington, P. E., McManus, S., Brugha, T., Meltzer, H., \& Howard, L. M. (2014). Gender differences in intimate partner violence and psychiatric disorders in England: Results from the 2007 adult psychiatric morbidity survey. Epidemiology and Psychiatric Sciences, 23(02), 189-199. http://doi.org/10.1017/S2 045796013000292

Lipp, M. N. (2005). Inventário de Sintomas de Stress para Adultos: Manual. São Paulo: Casa do Psicólogo.

Meneghel, S. N., Bairros, F., Mueller, B., Monteiro, D., Oliveira, L. P., \& Collaziol, M. E. (2011). Rotas críticas de mulheres em situação de violência: Depoimentos de mulheres e operadores em Porto Alegre, Rio Grande do Sul, Brasil. Cadernos de Saúde 
Pública, 27(4), 743-752. http://doi.org/10.1 590/S0102-311X2011000400013

Nunnally, J. C., \& Bernstein, I. H. (1994). Psychometric theory (3rd. ed.). New York: McGraw-Hill.

Ribeiro, W. S., Andreoli, S. B., Ferri, C. P., Prince, M., \& Mari, J. J. (2009). Exposição à violência e problemas de saúde mental em países em desenvolvimento: Uma revisão da literatura. Revista Brasileira Psiquiatria, 31 (Suppl. 2), 49-57. http://doi.org/10.1590 /S1516-44462009000600003

Sampieri, R. H., Collado, C. F., \& Lucio, M. P. (2013). Metodologia de pesquisa. Porto Alegre: Artmed.

Sant'Anna, P. A., \& Baima, A. P. S. (2008). Indicadores clínicos em psicoterapia com mulheres vítimas de abuso sexual. Psicologia Ciência e Profissão, 28(4), 728-741. http://doi.org/10.1590/S1414-989 32008000400006

Soares, M. C., Silva, G., Medeiros, C. M. R., Dias, M. D., \& Moura, J. P. (2013). Significados da Lei Maria da Penha para mulheres vítimas de violência doméstica. Revista Brasileira de Direito Constitucional, 21(1), 23-34. Retrieved from http://www.esdc.co $\mathrm{m} . \mathrm{br} / \mathrm{seer} /$ index.php/rbdc/article/view/11

Souza, F. B. C., Drezett, J., de Cássia Meirelles, A., \& Ramos, D. G. (2013). Aspectos psicológicos de mulheres que sofrem violência sexual. Reprodução $\mathcal{E}$ Climatério, 27(3), 98-103.https://doi.org/10.1016/j.recl i.2013.03.002

Steel, J., Sanna, L., Hammond, B., Whipple, J., \& Cross, H. (2003). Psychological sequelae of childhood sexual abuse: Abuserelated characteristics, coping strategies, and attributional style. Child Abuse $\mathcal{E}^{2}$ Neglect, 28, 785-801. http://doi.org/10.101 6/j.chiabu.2003.12.004

Ullman, S. E., \& Filipas, H. H. (2005). Gender differences in social reactions to abuse disclosures, post-abuse coping, and PTSD of child sexual abuse survivors. Child Abuse Eु Neglect, 29(7), 767 - 782. http://doi.org/1 0.1016/j.chiabu.2005.01.005
Van der Kolk, B., Roth, S., Pelcovitz, D., Sunday, S., \& Spinazzola, J. (2005). Disorders of extreme stress: The empirical foundation of a complex adaptation to trauma. Journal of Traumatic Stress, 18(5), 389-399. http://doi .org/10.1002/jts.20047

Vickerman, K. A., \& Margolin, G. (2009). Rape treatment outcome research: Empirical findings and state of the literature. Clinical Psychology Review, 29(5), 431-448. http://d oi.org/10.1016/j.cpr.2009.04.004

World Health Organization. (2013). Global and regional estimates of violence against women: Prevalence and health effects of intimate partner violence and non-partner sexual violence (Report). Geneva, Switzerland: Author. Retrieved from http://apps.who.int/iris/bitstream/106 65/85239/1/9789241564625_eng.pdf

\section{Notes}

* Research article. 